\title{
Seismic Response Improvement of Existing Prototype School Buildings Using Water Tanks, Port Said City, Egypt
}

\author{
Batool Wahba', Mohamed Sobaih'², Adel Akl² \\ ${ }^{1}$ Cairo University, Giza, Egypt \\ ${ }^{2}$ Department of Structural Engineering, Cairo University, Giza, Egypt \\ Email: eng.batool@gmail.com, msobaih2@yahoo.com, adelakl@gmail.com \\ Received 4 February 2016; accepted 11 March 2016; published 14 March 2016 \\ Copyright (C) 2016 by authors and Scientific Research Publishing Inc. \\ This work is licensed under the Creative Commons Attribution International License (CC BY). \\ http://creativecommons.org/licenses/by/4.0/ \\ (c) (i) Open Access
}

\section{Abstract}

There is a global trend for seismic response improvement of new buildings to reduce cost and future damage. It is also important to improve existing structures that are designed without consideration of seismic load or using old provisions that cannot meet the new one. The objective of this paper is to draw attention to evaluate existing reinforced concrete school buildings, then to present a proposed methodology to improve the behaviour of such schools with low cost especially in a developing country. The proposed method uses overhead water tanks as a tuned mass damper. A pushover analysis has been performed to evaluate the existing schools and perform a feasibility study to select the best solution to achieve seismic response improvement of the existing structure. Of course, the proposed methodology can be applied easily to other existing structures.

\section{Keywords}

Existing Structures, Tuned Mass damper (TMD), Seismic improvement, Pushover Analysis, Water Tank

\section{Introduction}

Egypt is a developing country and many buildings are not designed to sustain lateral seismic loads. Moreover, there is no governmental interest to evaluate, upgrade buildings to sustain lateral loads or to check buildings with current Egyptian code for loads.

Schools are considered lifeline structures in Egypt, because of its high occupancy, being used as a shelter in 
case of a catastrophic problem, and its importance to keep development in education and future.

After 1992 Dahshour Earthquake, the Egyptian government has established the Governmental Authority for Educational Buildings (GAEB) and released Egyptian code for loads ECP 201-1993 [1]. GAEB has designed schools as prototypes based on the number of classes and the capacity of each class. After the construction of schools, GAEB is interested in repair of non-structural elements, e.g. fences, windows, doors, etc. Moreover, GAEB does not have the authority to evaluate or upgrade of existing schools to sustain current lateral loads from ECP 201-2012 [2] that has been released and approved after ECP 201-1993.

This paper presents an evaluation of an existing school prototype building under 1993 and 2012 Egyptian codes, and then displays a proposed system for seismic response improvement. The proposed seismic improvement methodology is based on using water tanks as a Tuned Mass Damper (TMD). Pushover analysis is used as a tool and technique to evaluate the nonlinear behaviour of existing building and examine the feasibility of the proposed improvement method.

\section{Current Situation and Case Study Discussion}

Although many research works addressed the problem of seismic risk evaluation of existing building in Egypt [3]-[5], none of them has considered the nonlinear behaviour of such structures.

Port Said is a coastal city in Egypt and located in zone 3 on the seismic zone map [1] [2]. The building under study is an existing school building with a capacity of 33 classes as shown in Figure 1. The building is constructed in the nineties after 1992 Dahshour Earthquake. The building is designed to resist seismic loads as per ECP 201-93. Material characteristics of concrete and rebar are 25 MPA and 360 MPA, respectively. The building is five stories height with three bays in the $\mathrm{Y}$ direction and ten bays in the $\mathrm{X}$ direction. Most of the beams dimension varies from $250 \times 550 \mathrm{~mm}$ to $250 \times 800 \mathrm{~mm}$, while columns dimensions range from $300 \times 500 \mathrm{~mm}$ to $300 \times 800 \mathrm{~mm}$, and $140 \mathrm{~mm}$ slab thickness. Figure 2 displays typical story framing plan. Most of Port Said's Schools foundations are Raft or strap foundation; thus, the columns are considered with fixed supports.

SAP 2000 V17 [6] is used to evaluate the chosen prototype building. Two evaluation steps have been done, first to evaluate existing building using old ECP201-1993 code, second, to evaluate existing building using the current ECP 201-2012 code.

Table 1 displays summarized seismic factors selected from ECP 201-1993 and corresponding resultant base shear, while Table 2 displays summarized seismic factors selected from ECP 201-2012 and corresponding resultant base shear. It is noticed that the resultant base shear from ECP 201-2012 is greater than the resultant base shear from ECP-201 1993 by 50\%. The factors used in ECP 201-2012 are referenced from Eurocode 8 [7] that helped to use Eurocode 8 that built in SAP analysis.

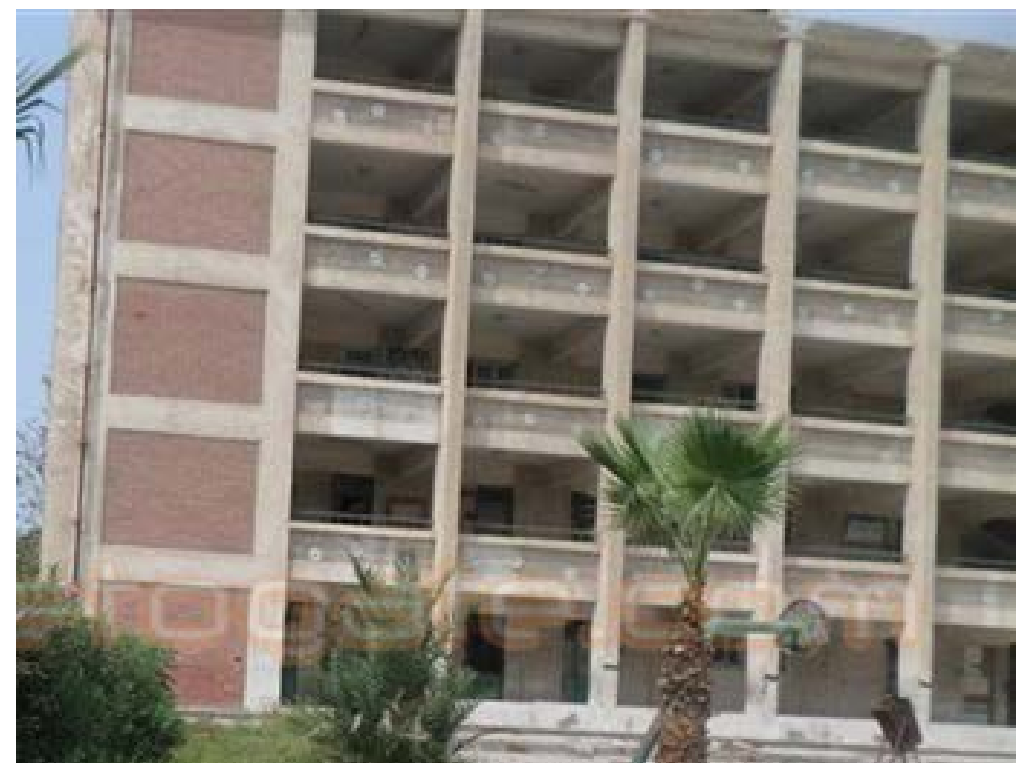

Figure 1. School building prototype. 


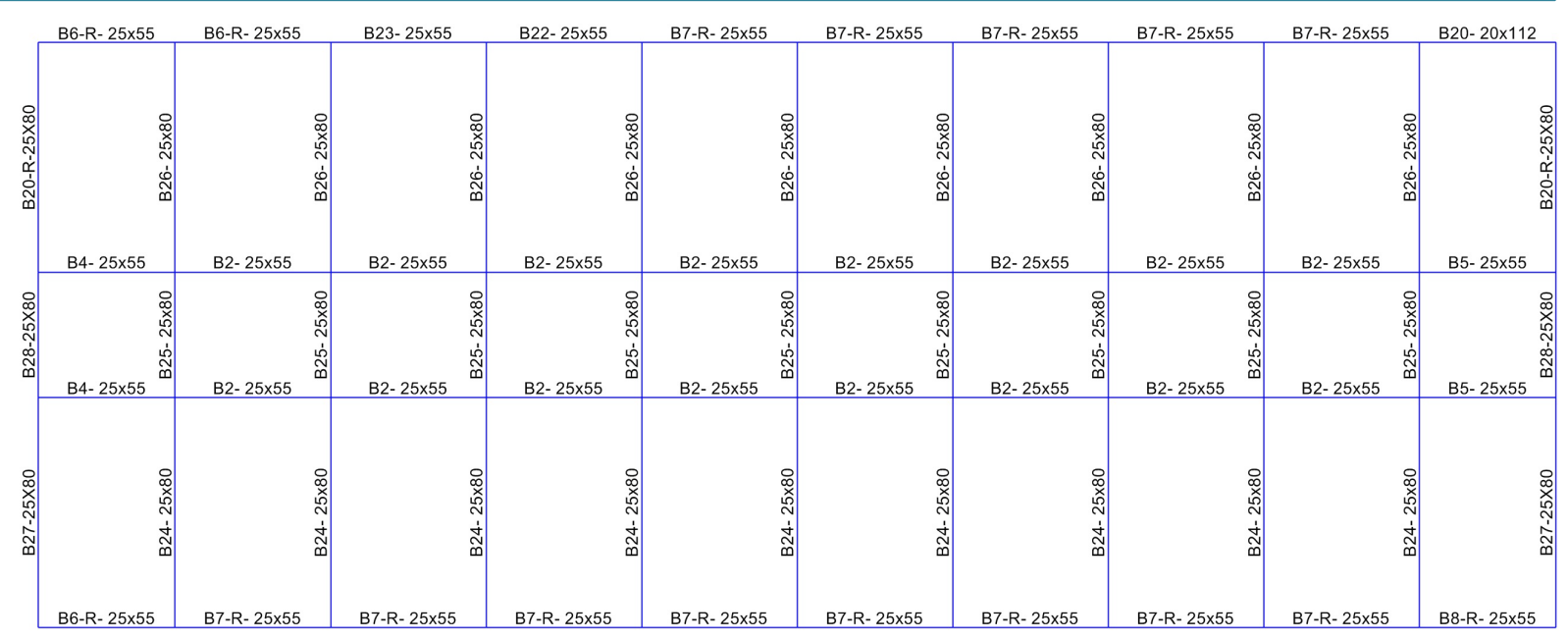

Figure 2. Typical story framing plan for school prototype.

Table 1. Seismic factors selected from ECP 201-1993 [1].

\begin{tabular}{cc}
\hline \multicolumn{2}{c}{ Base shear $=\mathrm{V}=$ ZICKSW } \\
\hline $\mathrm{Z}$ = Seismic zoning factor & 0.3 \\
$\mathrm{I}=$ Importance factor & 1.25 \\
$\mathrm{~T}$ = Period & $0.09 \mathrm{H} / \mathrm{B}$ \\
$\mathrm{K}=$ Structural system factor & 0.8 \\
$\mathrm{~S}$ = Soil factor & 1.15 \\
$\mathrm{~V}$ = Base shear & 109 ton (working load) \\
\hline
\end{tabular}

Table 2. Seismic factors selected from ECP 201-2012 [2].

$\begin{array}{cc}\text { Base shear }=\mathrm{Sd}(\mathrm{t})=\mathrm{ag} \gamma \mathrm{S} 2.5 / \mathrm{R} \\ \mathrm{ag}=\text { Ground acceleration } \\ \gamma=\text { Importance factor } & 0.15 \mathrm{~g} \\ \mathrm{~S}=\text { Soil factor } & 1.25 \\ \mathrm{R}=\text { Response modification factor } & 1.15 \\ \mathrm{~TB} & 5 \\ \mathrm{TC} & 0.2 \\ \mathrm{TD} & 0.6 \\ \mathrm{Ct} & 2 \\ \mathrm{~V}=\text { Base shear } & 0.075 \\ \end{array}$

After checking of the building elements, it is found that, the building is safe when subjected to the seismic load from ECP201-1993, as shown in Figure 3, while some vertical elements (columns) cannot sustain the seismic loads from the current ECP201-2012 as shown in Figure 4.

\section{Proposed Method to Improve Seismic Response of Existing Buildings}

\subsection{Use of Water Tanks as Tuned Mass Dampers (TMD)}

Liquid Mass Dampers have been used to stabilize marine vessels or to control a wobbling motion of satellites since 1950, and then was used in structural engineering to reduce lateral displacement. Many experimental and analytical studies have been done to measure the effectiveness of water damper. Some studies use water tanks as Tuned Mass Damper (TMD) based on Water-Structure mass ratio [8] and [9], while other researches use Tuned 
Liquid Damper TLD based on wave-structure interaction [10] to reduce lateral displacement of structures. Experimental studies [11] and analytical studies [12] for TLD have been carried out to evaluate the effect of TLD on structure behaviour. The use of TMD and TLD at the same time cannot be done in a developing country because TLD requires maintenance and special equipment to propagate wave sloshing.

Moreover, some researchers discuss the combination of TMD and TLD at the same model and its effect on earthquake response control of buildings [13] considering many parameters such as liquid height, mass, and frequency of water tank. A feasibility study of variable tanks as TMD has been implemented to improve the seismic response of structures during the design stage and select the optimum solution [14].

It worthy to mention that American code ACI 350.3 [15] and ECP 201-2012 [2] consider a design of tanks to

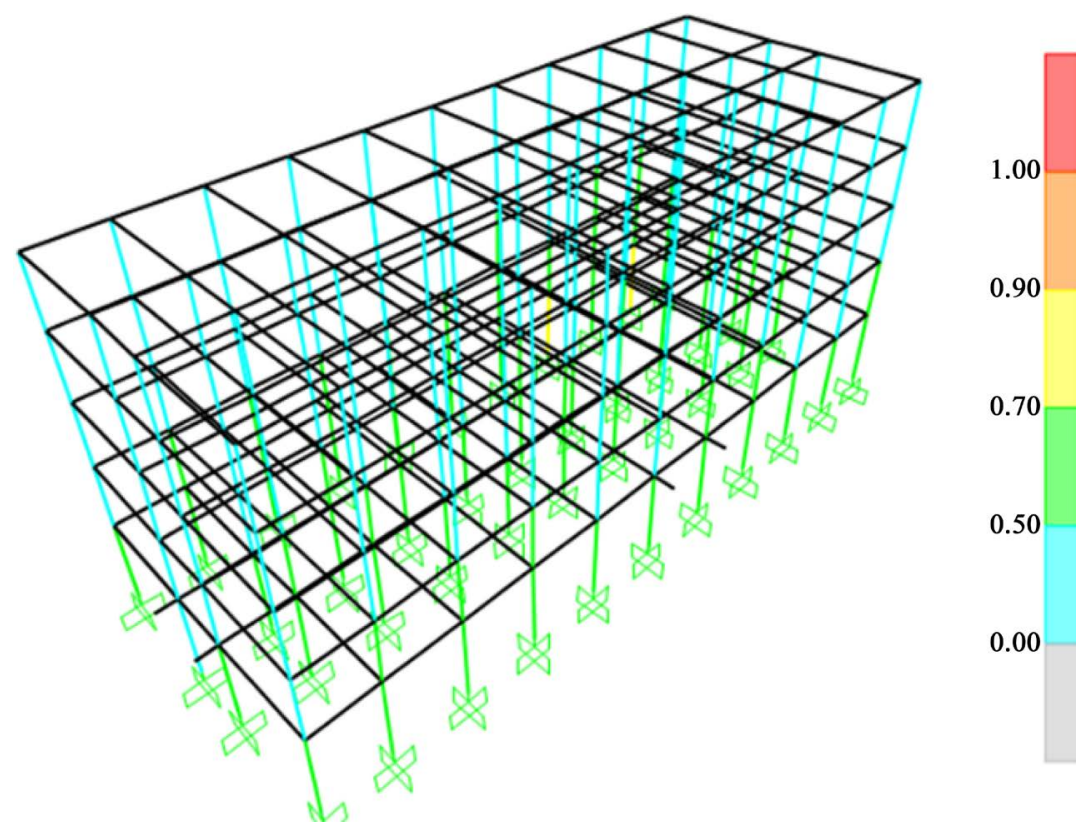

Figure 3. Elements are safe under application of ECP 201-1993 seismic loads.

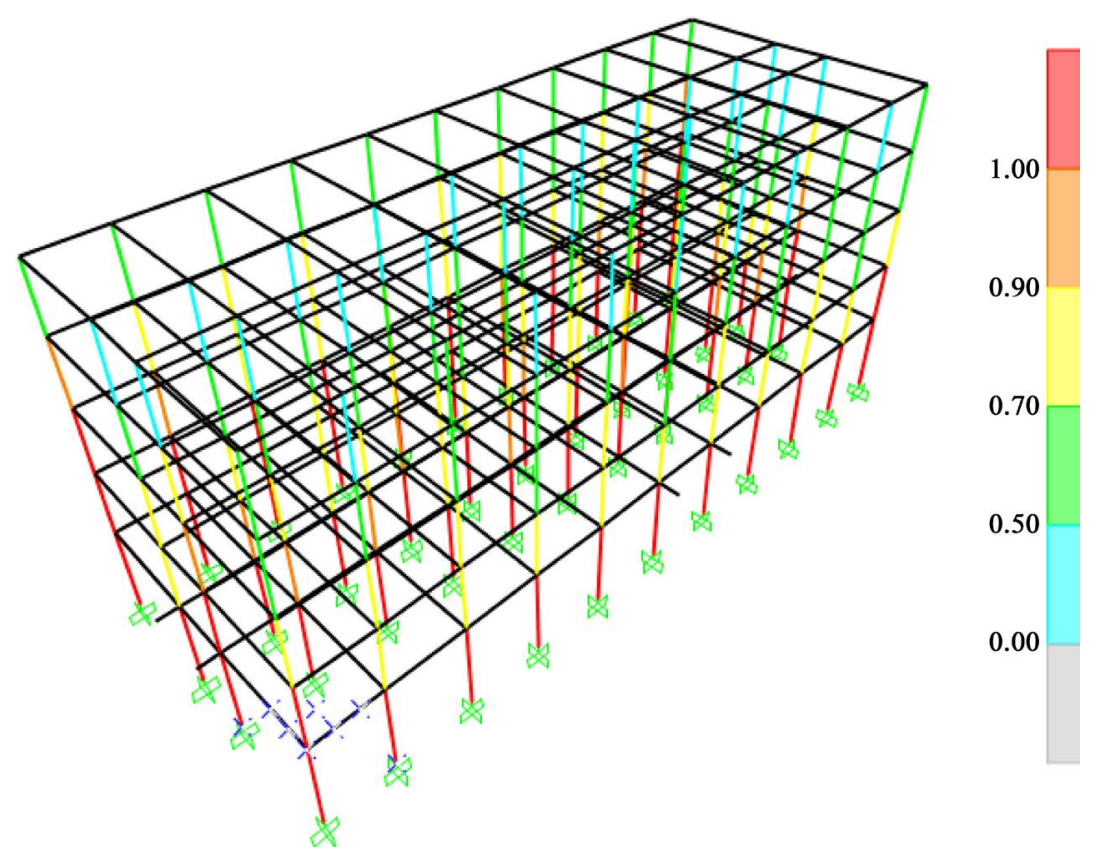

Figure 4. Some vertical elements cannot sustain current ECP 201-2012 seismic loads. 
resist lateral load developing from water structure interaction (impulsive and convective force), i.e., to design water containing tanks itself without considering the effect of tanks at the roof of structures.

\subsection{Application on TMD on a Case Study}

This paper presents a study for improvement of an existing school building in Port Said, Egypt. As Egypt is a developing country, the proposed methodology is to use tanks as a TMD. This paper presents an appropriate solution for existing important structures in developing country, and draws attention to improving seismic behaviour of existing structures with low cost using tanks to act in two options; the first is to satisfy the fire fighting requirement of Civil Defence Authority (CDA), second, is to improve the seismic response behaviour of the existing building.

This study has been done considering variation in the mass ratio (water to structure mass ratio $\mu$ ) in two cases. The first case with one tank at the centre of the roof area, the second case with two tanks on the roof located in a symmetrical position as displayed in Figure 5. Figure 6 shows a graph illustrating the 20 cases considered. For each case, it is considered that the variation of water height with fixation of tank dimensions and fixation of water height and variation of tank sizes. The total number of groups under this study is four groups each group contains five models with different mass ratio $\mu$. Table 3 presents all cases of tank mass damper.

Three-dimensional pushover analysis has been done for 20 models in X and Y direction using SAP $2000 \mathrm{~V} 17$. Then a feasibility study of various water TMDs is studied using pushover analysis. This feasibility study has been done to evaluate which case is the optimum solution to improve the seismic response of the existing building.

\section{Pushover Analysis}

Pushover analysis is a nonlinear static analysis which is widely used all over the world to evaluate of buildings. This paper uses pushover analysis as a tool to evaluate existing structure with and without tanks. The analysis procedure is done based on a gradually lateral movement of structure to reach a target displacement. The target displacement based on building height and applied lateral load. During this movement, there is a formation of plastic hinges in each step.
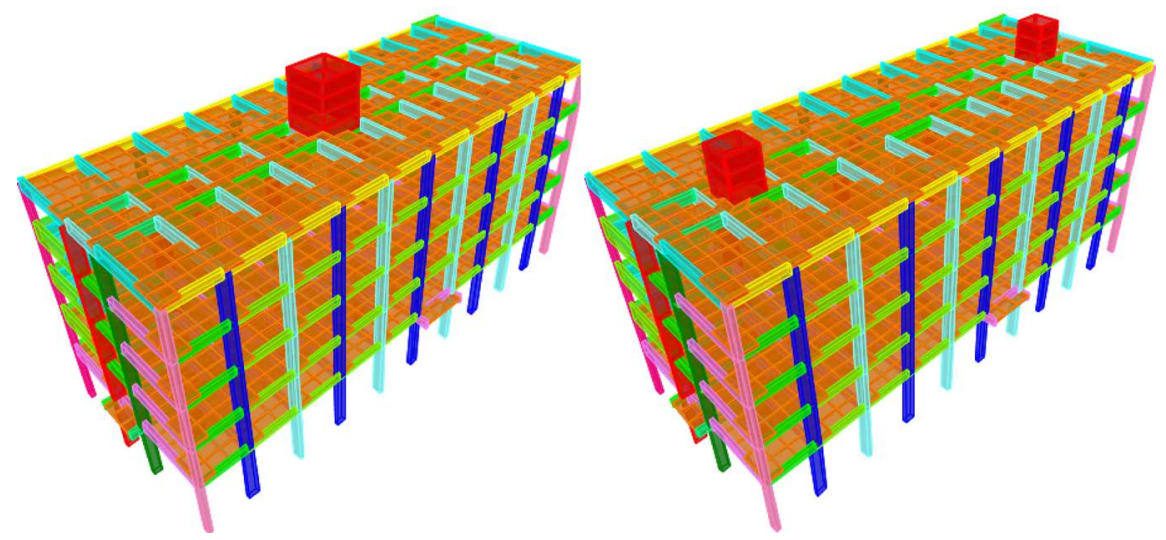

Figure 5. Case 1 with one tank and Case 2 with two tanks.

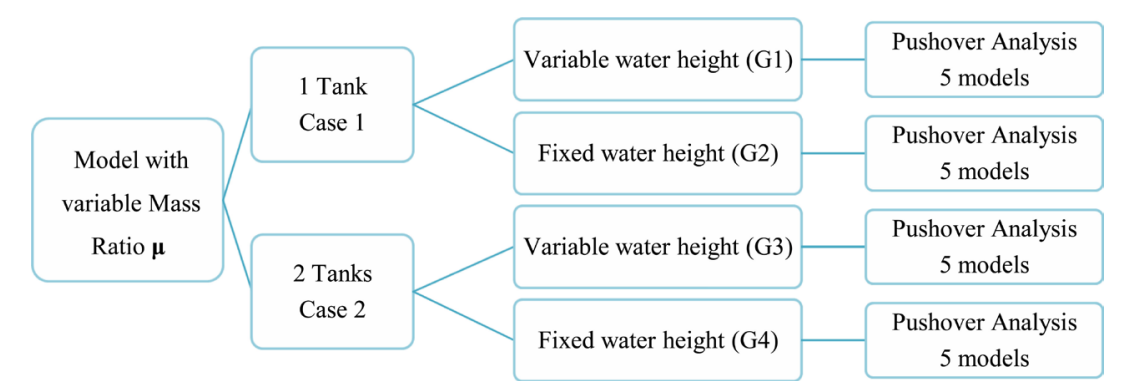

Figure 6. Graphical representation of considered cases. 


\subsection{Previous Studies}

Pushover analysis has been used in many researches as a technique to evaluate structures, and discuss nonlinear behaviour of structures such as:

- Devi and Nandini, (2015) [16], studied the seismic demand on reinforced concrete structures using pushover analysis. A Comparison between uniform and non-uniform structures has been done. They concluded that structures with a uniform profile in elevation have more lateral load capacity compared to structures with the non-uniform profile in elevation.

- Oyguc and Boduroglu, (2012) [17], presented a research paper on seismic capacity of irregular reinforced concrete structure using experimental studies on a prototype building, then compared results with threedimensional pushover analysis using SAP 2000.

- Bhatti, and Varum, (2012) [18], discussed the performance-based nonlinear static pushover analysis for the seismic design of reinforced concrete buildings.

- Yasrebinia and Pourshrifi (2012) [19], presented a study for three-dimensional analysis of irregular structures, using four, six and eight stories buildings. Then studied the variation of load pattern, load value and direction effect on results of three-dimensional pushover analysis.

- Ismaeil, (2014) [20], performed a pushover analysis to study and evaluate a four-story existing reinforced concrete flat slab building in the Sudan.

- Pednekar et al., (2015) [21], Performed three-dimension pushover analysis of reinforced concrete structures. The buildings under study have five, six and seven story. Finally, they compared the results between models.

\subsection{Technique of Evaluation}

The analysis using sap 2000 provides the capacity curve, i.e., the force-displacement curve as shown in Figure 7. This figure shows the level of plastic hinges [22] [23]. Besides, the analysis results provide the performance point where the capacity curve of the structure intersects the demand curve of the applied lateral load as shown in Figure 8 ATC-40 [22].

After reaching the performance point and corresponding $\mathrm{T}$ effective, one can indicate the level, number of plastic hinges and corresponding base shear. Table 4 presents the performance level of a building based on the definition of plastic hinges [23]. Figure 8 shows different stages of plastic hinges [22].

Table 3. Variation of tank size and water height considering variation of mass ratio $(\mu)$.

\begin{tabular}{|c|c|c|c|c|c|}
\hline \multirow{3}{*}{$\begin{array}{c}\text { Mass Ratio } \\
\mu\end{array}$} & \multirow{3}{*}{$\begin{array}{c}\text { Water Volume } \\
\mathrm{m}^{3}\end{array}$} & \multicolumn{2}{|c|}{1 Tank } & \multicolumn{2}{|c|}{2 Tank } \\
\hline & & $\begin{array}{l}\text { Variable Water Height } \\
\text { G1 }\end{array}$ & $\begin{array}{l}\text { Fixed Water Height } \\
\text { G2 }\end{array}$ & $\begin{array}{l}\text { Variable Water Height } \\
\text { G3 }\end{array}$ & $\begin{array}{c}\text { Fixed Water Height } \\
\text { G4 }\end{array}$ \\
\hline & & $\mathrm{B} \times \mathrm{L} \times \mathrm{H}(\mathrm{m})$ & $\mathrm{B} \times \mathrm{L} \times \mathrm{H}(\mathrm{m})$ & $\mathrm{B} \times \mathrm{L} \times \mathrm{H}(\mathrm{m})$ & $\mathrm{B} \times \mathrm{L} \times \mathrm{H}(\mathrm{m})$ \\
\hline $0.25 \%$ & 7.6 & $3 \times 3 \times 0.85$ & $1.95 \times 1.95 \times 2.00$ & $2 \times 2 \times 0.95$ & $1.38 \times 1.38 \times 2.00$ \\
\hline $0.50 \%$ & 15.2 & $3 \times 3 \times 1.69$ & $2.76 \times 2.76 \times 2.00$ & $2 \times 2 \times 1.90$ & $1.95 \times 1.95 \times 2.00$ \\
\hline $0.70 \%$ & 22.8 & $3 \times 3 \times 2.53$ & $3.38 \times 3.38 \times 2.00$ & $2 \times 2 \times 2.85$ & $2.38 \times 2.38 \times 2.00$ \\
\hline $1.00 \%$ & 30.4 & $3 \times 3 \times 3.78$ & $3.90 \times 3.90 \times 2.00$ & $2 \times 2 \times 3.80$ & $2.76 \times 2.76 \times 2.00$ \\
\hline $1.50 \%$ & 45.6 & $3 \times 3 \times 5.00$ & $4.78 \times 4.78 \times 2.00$ & $2 \times 2 \times 5.70$ & $3.38 \times 3.38 \times 2.00$ \\
\hline
\end{tabular}

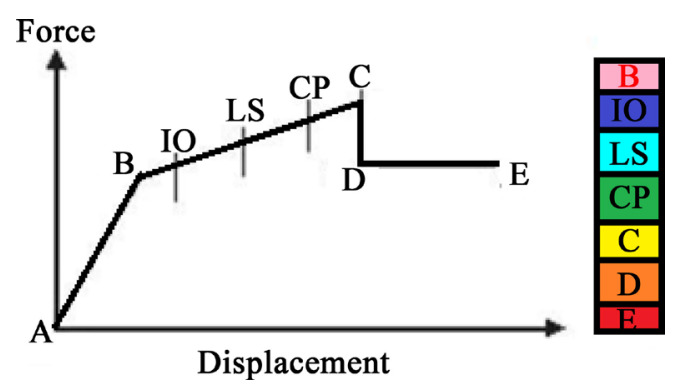

Figure 7. Different stages of plastic hinges. 


\section{Discussion of Results}

\subsection{Force-Displacement Curve}

Figure 9 displays force-displacement curve for the building without tanks in $\mathrm{X}$ and $\mathrm{Y}$ directions, while Figure 10 presents force-displacement curve for the building with tanks in $\mathrm{X}$ and $\mathrm{Y}$ direction. It is noted that the force-

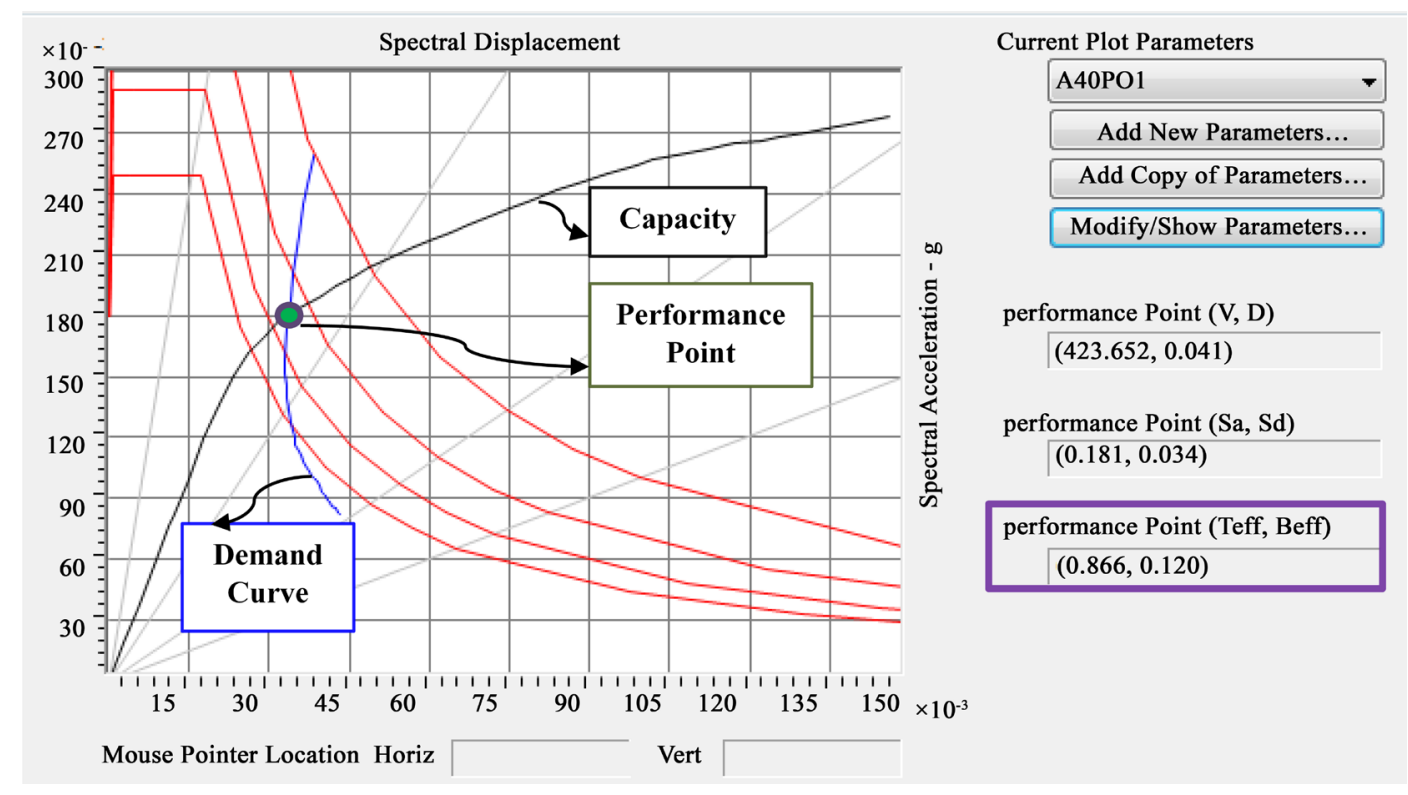

Figure 8. Pushover curve [22].

Table 4. Performance level of building [22].

\begin{tabular}{|c|c|}
\hline Level & Description \\
\hline Operational & Very light damage, no permanent drift, structure retains original strength and stiffness; all systems are normal \\
\hline $\begin{array}{l}\text { Immediate } \\
\text { Occupancy (IO) }\end{array}$ & $\begin{array}{l}\text { Light damage, no permanent drift, structure retains original strength and stiffness, elevator can be restarted, Fire } \\
\text { protection operable }\end{array}$ \\
\hline Life Safety (LS) & $\begin{array}{l}\text { Moderate damage, some permanent drift, some residual strength and stiffness left in all stories, damage to } \\
\text { partition, building may be beyond economical repair }\end{array}$ \\
\hline $\begin{array}{l}\text { Collapse Prevention } \\
\text { (CP) }\end{array}$ & $\begin{array}{l}\text { Severe damage, large displacement, little residual stiffness and strength but loading bearing column and wall } \\
\text { function, building is near collapse }\end{array}$ \\
\hline
\end{tabular}

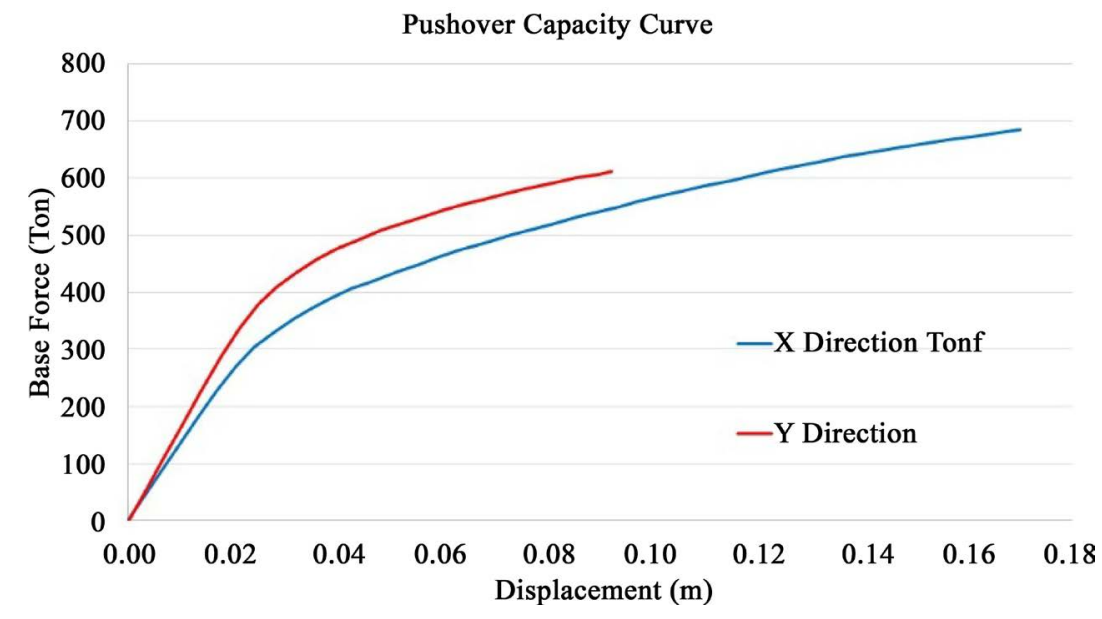

Figure 9. Force-displacement curve for building without tank. 
displacement curve is affected by the variation of mass ratio in the presence of one tank as shown in Figure 10(a) and Figure 10(b), while the force-displacement curve is not affected by variation of the mass ratio in the presence of two tanks as shown in Figure 10(c) and Figure 10(d).

\subsection{Performance Point and Formation of Plastic Hinges}

Table 5(a) and Table 5(b) display performance point and number of plastic hinges for building without tanks in $\mathrm{X}$ and Y-directions, respectively. While Table 6 presents a comparison between each group (with tanks) con-
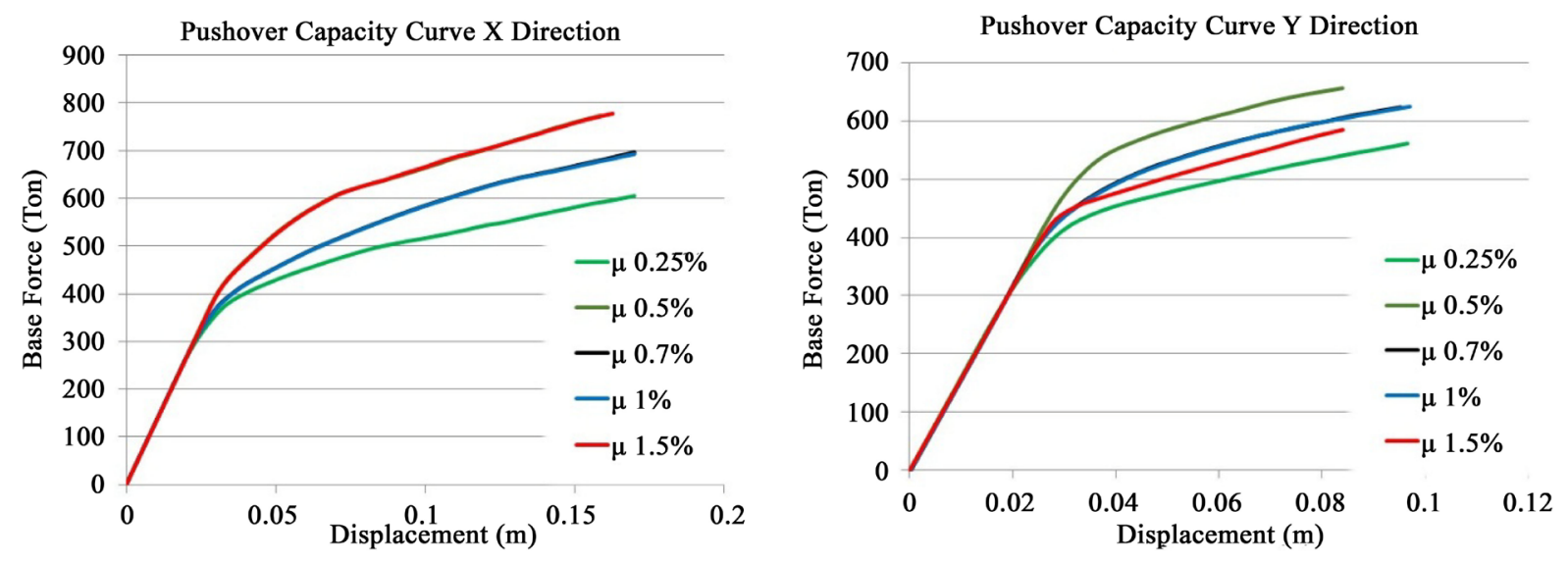

(a)
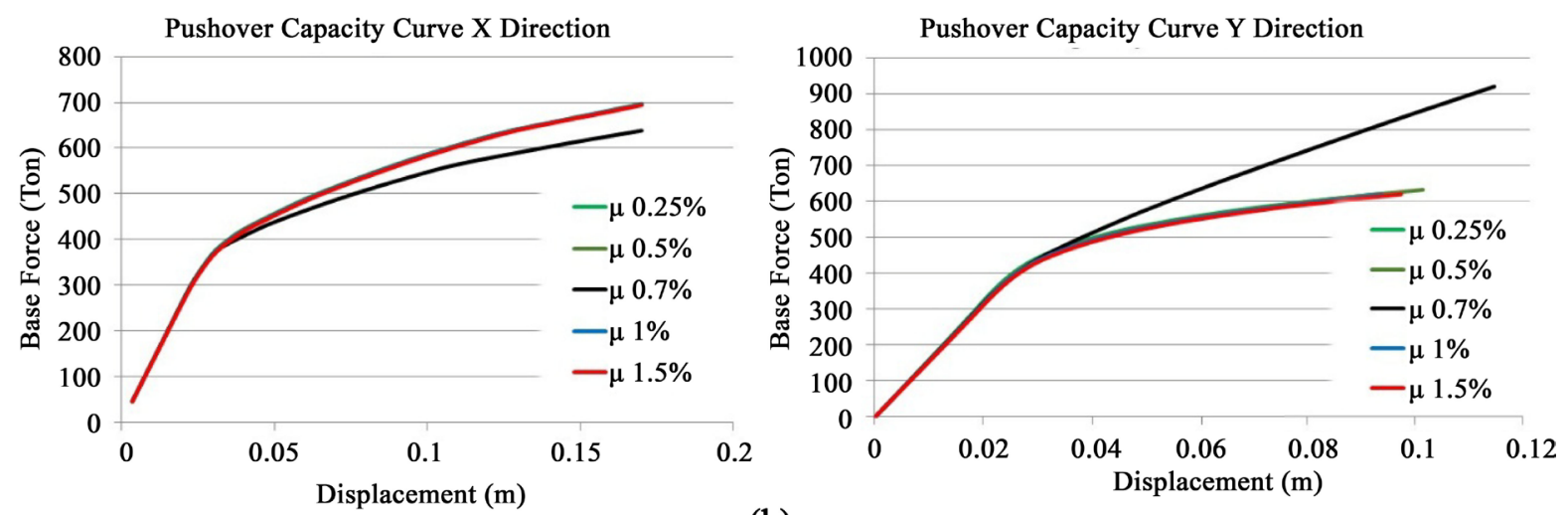

(b)
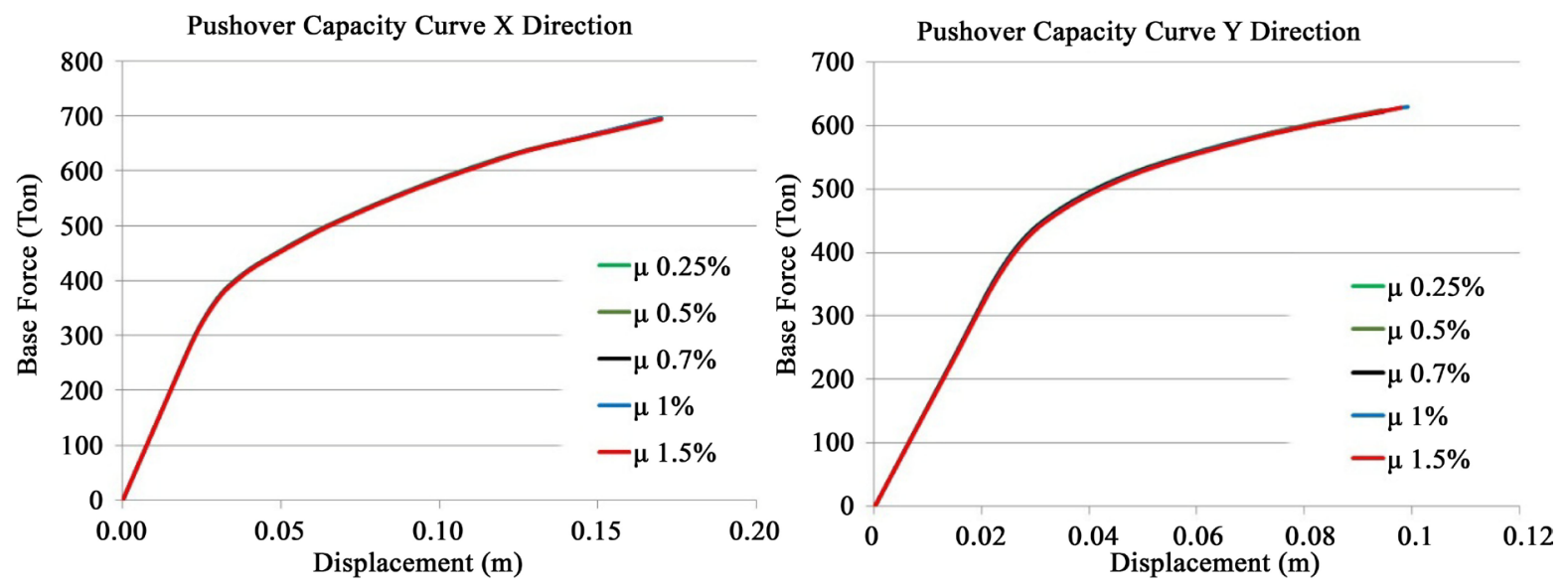

(c) 

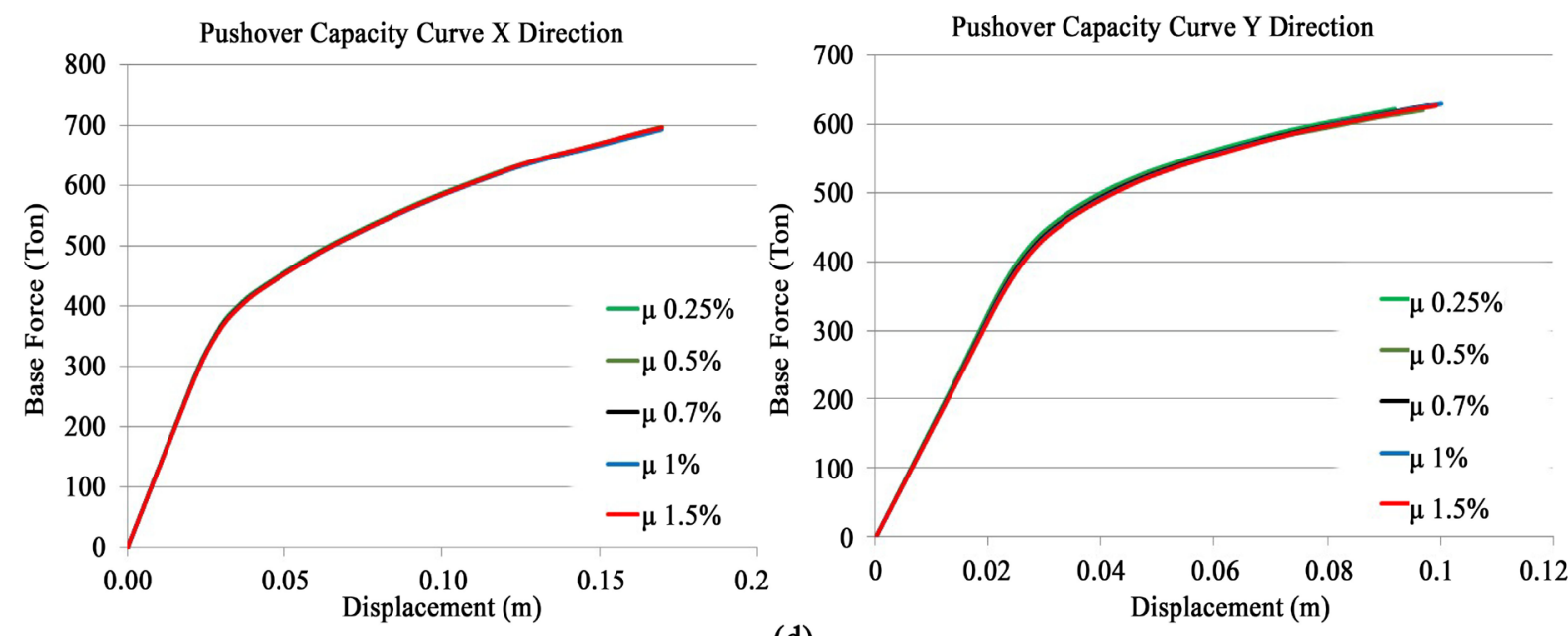

(d)

Figure 10. (a) Force-Displacement curve for building with 1 tank (G1), (b) force-Displacement curve for building with 1 tank (G2), (c) force-Displacement curve for building with 2 tanks (G3), (d) force-Displacement curve for building with 2 tanks (G4).

Table 5. (a) Performance points at X-Direction for building without tank, (b) performance points at Y-Direction for building without tanks.

(a)

\begin{tabular}{cccccccccc}
\hline Direction & Teff & Step & T & Base shear (ton) & Displacement (m) & B to IO & IO to LS & LS to CP \\
\hline \multirow{2}{*}{$\mathrm{X}$} & \multirow{2}{*}{1.124} & 22 & 1.1194 & 532.36 & 0.0860 & 464 & 1 & 0 \\
& & 23 & 1.1371 & 542.17 & 0.0901 & 467 & 7 & 0 \\
\hline
\end{tabular}

(b)

\begin{tabular}{cccccccccc} 
Direction & Teff & Step & $\mathrm{T}$ & Base shear (ton) & Displacement (m) & B to IO & IO to LS & LS to CP \\
Y & 1.107 & 12 & 1.0764 & 493.415 & 0.044 & 295 & 17 & 0 \\
& & 13 & 1.1106 & 509.186 & 0.048 & 305 & 23 & 0 \\
\hline
\end{tabular}

Table 6. (a) Comparison between performance points at X-Direction for (G1), (b) comparison between performance points at Y-Direction for (G1), (c) comparison between performance points at X-Direction for (G2), (d) comparison between performance points at Y-Direction for (G2), (e) comparison between performance points at X-Direction for (G3), (f) comparison between performance points at Y-Direction for (G3), (g) comparison between performance points at X-Direction for (G4), (h) comparison between performance points at Y-Direction for (G4).

(a)

\begin{tabular}{|c|c|c|c|c|c|c|c|c|}
\hline$\mu \%$ & Teff & Step & $\mathrm{T}$ & Base shear (ton) & Displacement (m) & B to IO & IO to LS & LS to $\mathrm{CP}$ \\
\hline \multirow{2}{*}{$0.25 \%$} & \multirow{2}{*}{1.193} & 21 & 1.1874 & 499.00 & 0.085 & 487 & 39 & 0 \\
\hline & & 22 & 1.2185 & 505.31 & 0.090 & 486 & 50 & 0 \\
\hline \multirow{2}{*}{$0.50 \%$} & \multirow{2}{*}{1.033} & 21 & 1.0185 & 618.47 & 0.075 & 521 & 21 & 0 \\
\hline & & 22 & 1.0505 & 627.53 & 0.080 & 512 & 35 & 0 \\
\hline \multirow{2}{*}{$0.70 \%$} & \multirow{2}{*}{1.108} & 22 & 1.0957 & 545.55 & 0.083 & 468 & 1 & 0 \\
\hline & & 23 & 1.1162 & 555.88 & 0.087 & 472 & 3 & 0 \\
\hline \multirow{2}{*}{$1.00 \%$} & \multirow{2}{*}{1.113} & 22 & 1.1128 & 551.70 & 0.086 & 471 & 2 & 0 \\
\hline & & 23 & 1.1311 & 561.09 & 0.090 & 475 & 8 & 0 \\
\hline \multirow{2}{*}{$1.50 \%$} & \multirow{2}{*}{1.043} & 21 & 1.0380 & 622.80 & 0.078 & 520 & 25 & 0 \\
\hline & & 22 & 1.0659 & 631.02 & 0.082 & 515 & 37 & 0 \\
\hline
\end{tabular}


(b)

\begin{tabular}{ccccccccc}
\hline$\mu \%$ & Teff & Step & T & Base shear (ton) & Displacement (m) & B to IO & IO to LS & LS to CP \\
\hline \multirow{2}{*}{$0.25 \%$} & \multirow{2}{*}{1.172} & 12 & 1.1618 & 463.98 & 0.044 & 318 & 32 & 0 \\
& & 13 & 1.1998 & 472.07 & 0.048 & 321 & 42 & 0 \\
$0.50 \%$ & \multirow{2}{*}{1.037} & 12 & 1.0038 & 551.02 & 0.040 & 345 & 26 & 0 \\
& & 13 & 1.0781 & 571.98 & 0.046 & 359 & 44 & 0 \\
$\mathbf{0 . 7 0 \%}$ & \multirow{2}{*}{1.093} & 14 & 1.0879 & 522.63 & 0.048 & 333 & $\mathbf{2 1}$ & 0 \\
& & 15 & 1.1281 & 536.22 & 0.052 & 345 & $\mathbf{3 0}$ & 0 \\
$\mathbf{1 . 0 0 \%}$ & \multirow{2}{*}{1.098} & 13 & 1.0673 & 511.96 & 0.045 & 317 & $\mathbf{1 6}$ & 0 \\
& & 14 & 1.0998 & 525.56 & 0.049 & 337 & $\mathbf{2 1}$ & 0 \\
$1.50 \%$ & \multirow{2}{*}{1.155} & 13 & 1.1466 & 489.89 & 0.045 & 225 & 56 & 0 \\
\hline
\end{tabular}

(c)

\begin{tabular}{|c|c|c|c|c|c|c|c|c|}
\hline$\mu \%$ & Teff & Step & $\mathrm{T}$ & Base shear (ton) & Displacement (m) & B to IO & IO to LS & LS to $\mathrm{CP}$ \\
\hline \multirow{2}{*}{$0.25 \%$} & \multirow{2}{*}{1.096} & 22 & 1.0856 & 546.25 & 0.082 & 466 & 1 & 0 \\
\hline & & 23 & 1.1015 & 554.62 & 0.086 & 470 & 2 & 0 \\
\hline \multirow{2}{*}{$0.50 \%$} & \multirow{2}{*}{1.102} & 27 & 1.1881 & 596.37 & 0.105 & 491 & 37 & 0 \\
\hline & & 28 & 1.2096 & 607.72 & 0.111 & 490 & 47 & 0 \\
\hline \multirow{2}{*}{$0.70 \%$} & \multirow{2}{*}{1.156} & 23 & 1.1488 & 518.97 & 0.085 & 521 & 0 & 0 \\
\hline & & 24 & 1.1667 & 526.49 & 0.089 & 529 & 0 & 0 \\
\hline \multirow{2}{*}{$1.00 \%$} & \multirow{2}{*}{1.11} & 22 & 1.0970 & 545.47 & 0.083 & 468 & 1 & 0 \\
\hline & & 23 & 1.1159 & 555.31 & 0.087 & 471 & 3 & 0 \\
\hline \multirow{2}{*}{$1.50 \%$} & \multirow{2}{*}{1.12} & 22 & 1.1180 & 550.76 & 0.086 & 472 & 2 & 0 \\
\hline & & 23 & 1.1419 & 563.43 & 0.091 & 475 & 12 & 0 \\
\hline
\end{tabular}

(d)

\begin{tabular}{ccccccccc}
\hline$\mu \%$ & Teff & Step & T & Base shear (ton) & Displacement (m) & B to IO & IO to LS & LS to CP \\
\hline \multirow{2}{*}{$0.25 \%$} & \multirow{2}{*}{1.08} & 13 & 1.0625 & 515.36 & 0.044 & 316 & 18 & 0 \\
& & 14 & 1.0981 & 529.39 & 0.048 & 338 & 26 & 0 \\
\multirow{2}{*}{$0.50 \%$} & \multirow{2}{*}{1.087} & 13 & 1.0631 & 513.84 & 0.045 & 313 & 17 & 0 \\
& & 14 & 1.0957 & 527.19 & 0.049 & 338 & 23 & 0 \\
$\mathbf{0 . 7 0 \%}$ & \multirow{2}{*}{0.985} & 17 & 0.9772 & 650.44 & 0.063 & 287 & 0 & 0 \\
& & 18 & 0.9931 & 686.27 & 0.069 & 290 & 0 & 0 \\
$1.00 \%$ & \multirow{2}{*}{1.096} & 14 & 1.0898 & 523.00 & 0.048 & 334 & 21 & 0 \\
& & 15 & 1.1309 & 537.56 & 0.053 & 345 & 30 & 0 \\
$\mathbf{1 . 5 0 \%}$ & \multirow{2}{*}{1.107} & 13 & 1.0639 & 507.50 & 0.045 & 320 & $\mathbf{1 0}$ & 0 \\
\hline
\end{tabular}

(e)

\begin{tabular}{ccccccccc}
\hline$\mu \%$ & Teff & Step & T & Base shear (ton) & Displacement (m) & B to IO & IO to LS & LS to CP \\
\hline \multirow{2}{*}{$0.25 \%$} & \multirow{2}{*}{1.105} & 21 & 1.0961 & 499.00 & 0.0851 & 462 & 1 & 0 \\
& & 22 & 1.1167 & 505.31 & 0.0900 & 467 & 4 & 0 \\
$0.50 \%$ & \multirow{2}{*}{1.108} & 22 & 1.0983 & 557.59 & 0.0878 & 469 & 4 & 0 \\
& & 23 & 1.1198 & 570.69 & 0.0934 & 469 & 20 & 0 \\
$\mathbf{0 . 7 0 \%}$ & \multirow{2}{*}{1.11} & 22 & 1.0896 & 541.05 & 0.0811 & 460 & 0 & 0 \\
& & 23 & 1.1183 & 555.75 & 0.0872 & 467 & $\mathbf{3}$ & 0 \\
$\mathbf{1 . 0 0 \%}$ & \multirow{2}{*}{1.114} & 21 & 1.0937 & 541.37 & 0.0813 & 461 & $\mathbf{0}$ & 0 \\
& & 22 & 1.1210 & 555.58 & 0.0872 & 469 & $\mathbf{2}$ & 0 \\
$\mathbf{1 . 5 0 \%}$ & \multirow{2}{*}{1.12} & 21 & 1.1054 & 544.45 & 0.0830 & 463 & $\mathbf{1}$ & 0 \\
\hline
\end{tabular}


(f)

\begin{tabular}{|c|c|c|c|c|c|c|c|c|}
\hline$\mu \%$ & Teff & Step & $\mathrm{T}$ & Base shear (ton) & Displacement (m) & $\mathrm{B}$ to $\mathrm{IO}$ & IO to $\mathrm{LS}$ & LS to $\mathrm{CP}$ \\
\hline \multirow{2}{*}{$0.25 \%$} & \multirow{2}{*}{1.09} & 13 & 1.0694 & 514.96 & 0.0448 & 318 & 18 & 0 \\
\hline & & 14 & 1.1036 & 528.74 & 0.0489 & 339 & 24 & 0 \\
\hline \multirow{2}{*}{$0.50 \%$} & \multirow{2}{*}{1.093} & 13 & 1.0729 & 571.98 & 0.0459 & 319 & 17 & 0 \\
\hline & & 14 & 1.1027 & 584.83 & 0.0501 & 338 & 23 & 0 \\
\hline \multirow{2}{*}{$0.70 \%$} & \multirow{2}{*}{1.095} & 13 & 1.0683 & 511.99 & 0.0443 & 317 & 17 & 0 \\
\hline & & 14 & 1.1026 & 526.32 & 0.0485 & 334 & 23 & 0 \\
\hline \multirow{2}{*}{$1.00 \%$} & \multirow{2}{*}{1.099} & 13 & 1.0693 & 511.41 & 0.0446 & 316 & 16 & 0 \\
\hline & & 14 & 1.1004 & 525.07 & 0.0485 & 334 & 21 & 0 \\
\hline \multirow{2}{*}{$1.50 \%$} & \multirow{2}{*}{1.104} & 11 & 1.0075 & 479.74 & 0.0376 & 303 & $\mathbf{0}$ & 0 \\
\hline & & 12 & 1.0422 & 496.38 & 0.0413 & 317 & 5 & 0 \\
\hline
\end{tabular}

(g)

\begin{tabular}{|c|c|c|c|c|c|c|c|c|}
\hline$\mu \%$ & Teff & Step & $\mathrm{T}$ & Base shear (ton) & Displacement (m) & B to IO & IO to LS & LS to CP \\
\hline \multirow{2}{*}{$0.25 \%$} & \multirow{2}{*}{1.096} & 21 & 1.0760 & 541.72 & 0.080 & 459 & $\mathbf{0}$ & 0 \\
\hline & & 22 & 1.1031 & 555.77 & 0.086 & 467 & 2 & 0 \\
\hline \multirow{2}{*}{$0.50 \%$} & \multirow{2}{*}{1.104} & 18 & 1.0025 & 501.17 & 0.065 & 427 & $\mathbf{0}$ & 0 \\
\hline & & 19 & 1.0231 & 511.07 & 0.069 & 434 & $\mathbf{0}$ & 0 \\
\hline \multirow{2}{*}{$0.70 \%$} & \multirow{2}{*}{1.109} & 21 & 1.0968 & 545.78 & 0.083 & 461 & 1 & 0 \\
\hline & & 22 & 1.1201 & 557.80 & 0.088 & 471 & 3 & 0 \\
\hline \multirow{2}{*}{$1.00 \%$} & \multirow{2}{*}{1.116} & 22 & 1.0981 & 542.97 & 0.082 & 462 & 1 & 0 \\
\hline & & 23 & 1.1198 & 553.98 & 0.087 & 468 & 2 & 0 \\
\hline \multirow{2}{*}{$1.50 \%$} & \multirow{2}{*}{1.124} & 28 & 1.2320 & 607.99 & 0.111 & 475 & 50 & 0 \\
\hline & & 29 & 1.2570 & 620.45 & 0.118 & 486 & 53 & 0 \\
\hline
\end{tabular}

(h)

\begin{tabular}{|c|c|c|c|c|c|c|c|c|}
\hline$\mu \%$ & Teff & Step & $\mathrm{T}$ & Base shear (ton) & Displacement (m) & $\mathrm{B}$ to $\mathrm{IO}$ & IO to LS & LS to $\mathrm{CP}$ \\
\hline \multirow{2}{*}{$0.25 \%$} & \multirow{2}{*}{1.081} & 13 & 1.0660 & 515.88 & 0.044 & 316 & 20 & 0 \\
\hline & & 14 & 1.1080 & 531.41 & 0.049 & 335 & 30 & 0 \\
\hline \multirow{2}{*}{$0.50 \%$} & \multirow{2}{*}{1.089} & 13 & 1.0709 & 515.78 & 0.045 & 318 & 18 & 0 \\
\hline & & 14 & 1.1019 & 528.27 & 0.049 & 339 & 23 & 0 \\
\hline \multirow{2}{*}{$0.70 \%$} & \multirow{2}{*}{1.094} & 13 & 1.0720 & 514.74 & 0.045 & 318 & 17 & 0 \\
\hline & & 14 & 1.1033 & 527.57 & 0.049 & 339 & 22 & 0 \\
\hline \multirow{2}{*}{$1.00 \%$} & \multirow{2}{*}{1.101} & 13 & 1.0753 & 513.82 & 0.046 & 318 & 16 & 0 \\
\hline & & 14 & 1.1038 & 526.13 & 0.049 & 334 & 21 & 0 \\
\hline \multirow{2}{*}{$1.50 \%$} & \multirow{2}{*}{1.108} & 13 & 1.0793 & 513.14 & 0.046 & 318 & 16 & 0 \\
\hline & & 14 & 1.1067 & 525.47 & 0.049 & 335 & 21 & 0 \\
\hline
\end{tabular}

sidering performance points and number of plastic hinges in both directions $\mathrm{X}$ and $\mathrm{Y}$.

Comparing the results shown in Table 5 and Table 6 it is noticed that; the model with $0.7 \%$ mass ratio give the best results as far as the number and type of plastic hinges. This will lead to improving the seismic response of the studied prototype building. This is summarized in Table 7 which displays a comparison between performance points and number of plastic hinges in all cases with $\mu=0.7 \%$ in both directions $\mathrm{X}$ and Y. This confirms that the G2 group with $0.7 \%$ mass ratio is the best solution for the seismic improvement of the chosen building.

\subsection{Comparison with Previous Results}

This study shows that; the use of one tank has a significant effect on improving the seismic response of the 
Table 7. Comparison between performance points at X and Y-Directions for all groups with $\mu=0.7 \%$.

\begin{tabular}{|c|c|c|c|c|c|c|c|c|c|c|c|c|}
\hline & $\mu=0.7 \%$ & & Direction & Teff & Step & $\mathrm{T}$ & $\begin{array}{l}\text { Base shear } \\
\text { (ton) }\end{array}$ & $\begin{array}{l}\text { Displacement } \\
\text { (m) }\end{array}$ & $\begin{array}{l}\text { B to } \\
\text { IO }\end{array}$ & $\begin{array}{l}\text { IO to } \\
\text { LS }\end{array}$ & $\begin{array}{l}\text { LS to } \\
\text { CP }\end{array}$ & Rank \\
\hline \multirow{8}{*}{1 Tank } & \multirow{4}{*}{$\begin{array}{c}\text { Variable water } \\
\text { height }\end{array}$} & \multirow{4}{*}{ G1 } & \multirow{2}{*}{$\mathrm{X}$} & \multirow{2}{*}{1.108} & 22 & 1.0957 & 545.55 & 0.083 & 468 & 1 & 0 & \multirow{4}{*}{$\mathrm{D}$} \\
\hline & & & & & 23 & 1.1162 & 555.88 & 0.087 & 472 & 3 & 0 & \\
\hline & & & \multirow{2}{*}{$\mathrm{Y}$} & \multirow{2}{*}{1.093} & 14 & 1.0879 & 522.63 & 0.048 & 333 & 21 & 0 & \\
\hline & & & & & 15 & 1.1281 & 536.22 & 0.052 & 345 & 30 & 0 & \\
\hline & \multirow{4}{*}{$\begin{array}{l}\text { Fixed water } \\
\text { height }\end{array}$} & \multirow{4}{*}{ G2 } & \multirow{2}{*}{$\mathrm{X}$} & \multirow{2}{*}{1.156} & 23 & 1.1488 & 518.97 & 0.085 & 521 & 0 & 0 & \multirow{4}{*}{ A } \\
\hline & & & & & 24 & 1.1667 & 526.49 & 0.089 & 529 & 0 & 0 & \\
\hline & & & \multirow{2}{*}{$\mathrm{Y}$} & \multirow{2}{*}{0.985} & 17 & 0.9772 & 650.44 & 0.063 & 287 & 0 & 0 & \\
\hline & & & & & 18 & 0.9931 & 686.27 & 0.069 & 290 & 0 & 0 & \\
\hline \multirow{8}{*}{2 Tank } & \multirow{4}{*}{$\begin{array}{c}\text { Variable water } \\
\text { height }\end{array}$} & \multirow{4}{*}{ G3 } & \multirow{2}{*}{$\mathrm{X}$} & \multirow{2}{*}{1.11} & 22 & 1.0896 & 541.05 & 0.0811 & 460 & 0 & 0 & \multirow{4}{*}{$\mathrm{C}$} \\
\hline & & & & & 23 & 1.1183 & 555.75 & 0.0872 & 467 & 3 & 0 & \\
\hline & & & \multirow{2}{*}{$\mathrm{Y}$} & \multirow{2}{*}{1.095} & 13 & 1.0683 & 511.99 & 0.0443 & 317 & 17 & 0 & \\
\hline & & & & & 14 & 1.1026 & 526.32 & 0.0485 & 334 & 23 & 0 & \\
\hline & \multirow{4}{*}{$\begin{array}{l}\text { Fixed water } \\
\text { height }\end{array}$} & \multirow{4}{*}{ G4 } & \multirow{2}{*}{$\mathrm{X}$} & \multirow{2}{*}{1.109} & 21 & 1.0968 & 545.78 & 0.083 & 461 & 1 & 0 & \multirow{4}{*}{ B } \\
\hline & & & & & 22 & 1.1201 & 557.80 & 0.088 & 471 & 3 & 0 & \\
\hline & & & \multirow{2}{*}{$\mathrm{Y}$} & \multirow{2}{*}{1.094} & 13 & 1.0720 & 514.74 & 0.045 & 318 & 17 & 0 & \\
\hline & & & & & 14 & 1.1033 & 527.57 & 0.049 & 339 & 22 & 0 & \\
\hline
\end{tabular}

studied building more than the use of two tanks. However Patil et al. [9] found that the use of multiple mass dampers gave better results for the overall displacement of the structure. This can be explained by the fact that; his results have been obtained without considering the nonlinear behaviour of the structure as in this paper.

The results obtained herein agrees with those obtained by Dattatray et al. [8] that show that tanks with $1 / 2$ to 2/3 water depth have better effect more than full tanks, as shown in Table 3.

Besides, the mass ratio of $0.7 \%$ that gives best results agrees with the mass ratio of $0.7 \%$ to $3 \%$ obtained by Dattatray et al. [8] and Tejashri et al. [14].

It is worthy to mention that; the present study considers the nonlinear behaviour of structure while other previous studies considered the static linear analysis.

\section{Summary and Conclusions}

Seismic response evaluation has been done for existing school prototype building based on the current code for loads, and some vertical elements could not sustain seismic loads. Use the water Tank as TMD is the proposed methodology to improve seismic response for the building. Pushover analysis is performed as a tool to identify the best tank from 20 proposals for different mass ratios, water heights, tank dimensions and number of tanks. It is found that:

1) Using one tank is better than using two tanks with the same mass ratio, and this result is presented in the force-displacement curve.

2) The mass ratio of $0.7 \%$ is the best value that can improve the seismic behaviour of the existing prototype school building.

3) Not all the discussed tanks can upgrade the seismic building performance. Some of them decrease the building performance, so it is important to make iterations to select the best solution.

4) The proposed methodology is economical and can be easily performed in all existing reinforced concrete school buildings as it satisfies the following criteria.

a) Meet the civil defence requirement for adding tanks at the roof for fire fighting purposes.

b) Improve seismic performance of the structure.

c) Tanks as a TMD do not need maintenance, just to keep water volume constant.

5) In General, the mass ratio of $0.5 \%$ to $1.0 \%$ gives better performance more than the other mass ratios.

Therefore, it is recommended that: 
1) The proposed methodology can be applied in old buildings to improve the seismic response of structures.

2) The proposed method is economical and the tanks are used for fire fighting and plumbing issue and are used to improve the seismic response of structures, so it is appropriate for developing countries.

3) Three-dimensional pushover analysis can be done to evaluate existing buildings.

4) For the new buildings, it is important to study the effect of top roof tanks on the behaviour of structure regarding lateral loads.

5) American (ACI) and Egyptian (ECP) codes should pay attention to the top-roof tanks. As some can improve the response of structures while others can be harmful to the structure in case of seismic loads.

\section{Acknowledgements}

The authors would like to thank the Governmental Authority for Educational Buildings (GAEB) at Port Said city, Egypt. The research in this paper is based on the data for the existing schools provided by GAEB.

\section{References}

[1] Egyptian Code for Loads, ECP 201-1993, Prepared by National Housing and Construction Research Centre.

[2] Egyptian Code for Loads, ECP 201-2012, National Housing and Construction Research Centre.

[3] Sobaih, M., El-Ramaily, A. and Kebeasy, R. (1992) Seismic Risk Evaluation of Urban Areas in Egypt. International Journal of Earthquake Engineering, 2, 91-119.

[4] Sobaih, M., et al. (1997) Seismic Risk Evaluation of highway Bridges. 2nd Egyptian Conference in Earthquake Engineering, EGYQUAKE2, Aswan, 1-3 November 1997, 305-325

[5] Nazif, M. and Sobaih, M. (2012) A Proposed Methodology for Seismic Risk Evaluation of Existing Reinforced School Buildings. HBRC Journal, 8, 204-211.

[6] CSI.SAP 2000 V-17 (2010) Integrated Finite Element Analysis and Design of Structures Basic Analysis Reference Manual. Berkeley.

[7] EuroCode 08 (2011) Design of Structures for Earthquake Resistance, Part 1, General Rules, Seismic Actions and Rules for Buildings. The European Union per Regulation 305/2011, Directive 98/34/EC, Directive 2004/18/E.

[8] Dattatray, B., Patil, G.R. and Maskar, S. (2014) Use of Overhead Water Tank to Reduce Peak Response of the Structure. International Journal of Innovative Technology and Exploring Engineering, 4, 60-64.

[9] Patil S.S., Javheri S.B. and Konapure C.G. (2012) Effectiveness of Multiple Tuned Mass Dampers. International Journal of Engineering and Innovative Technology (IJEIT), 1, 78-83.

[10] Bhattacharjee, E., Halder, L. and Sharma, P.R. (2013) An Experimental Study on Tuned Liquid Damper for Mitigation of Structural Response. International Journal of Advanced Structural Engineering. http://link.springer.com/article/10.1186/2008-6695-5-3/fulltext.html

[11] Mondal, J., Nimmala, H., Abdulla, S. and Tafreshi, R. (2014) Tuned Liquid Damper. The 3rd International Conference on Mechanical Engineering and Mechatronics, Prague, 14-15 August 2014, Paper No. 68.

[12] Samanta, A. and Banerji, P. (2008) Structural Control Using Modified Tuned Liquid Dampers. The 14th World Conference on Earthquake Engineering, 14WCEE, Beijing, 12-17 October 2008, 1-8.

[13] Novo, T., Varum, H., Teixeira-Dias, F., Rodrigues, H., Falcao, S.M., Campos, C.A. and Guerreiro, L. (2013) Tuned Liquid Dampers Simulation for Earthquake Response Control of Buildings. The 15th World Conference on Earthquake Engineering, 15WCEE, Lisbon, 24-28 September 2012, Paper No. 5631.

[14] Gulve, T.S. and Murnal, P. (2013) Feasibility of Implementing Water Tank as Passive Tuned Mass Damper. International Journal of Innovative Technology and Exploring Engineering, 3, 12-19.

[15] ACI 350.3-01, Seismic Design of Liquid-Containing Concrete Structures, Reported by ACI Committee 350, Environmental Engineering Concrete Structures.

[16] Devi, S. and Nandini Devi, G. (2015) Seismic Demand Study on RC Structural Systems Using Pushover Analysis an Overview. International Journal of Innovative Research in Science, Engineering and Technology, 4, 9719-9720.

[17] Oyguc, A. and Boduroglu, H. (2012) Seismic Capacity Assessment of Existing Irregular Reinforced Concrete (RC) Buildings by an Adaptive Three-Dimensional Pushover Procedure. The 15th World Conference on Earthquake Engineering, 15WCEE, Lisbon, 24-28 September 2012, Paper No. 815.

[18] Bhatti, A.Q. and Varum, H. (2012) Application of Performance Based Nonlinear Seismic Design and Simulation Static Pushover Analysis for Seismic Design of RC Buildings. Proceedings of the 15th World Conference on Earthquake Engineering, 15WCEE, Lisbon, 24-28 September 2012, Paper No. 1411. 
[19] Yasrebinia, Y. and Pourshrifi, M. (2012) Investigation the 3D-Pushover Analysis of Unsymmetrical Concrete Structures. Proceedings of the 15th World Conference on Earthquake Engineering, 15WCEE, Lisbon, 24-28 September 2012, Paper No. 1987.

[20] Ismaeil, M.A. (2014) Pushover Analysis of Existing 3 Stories RC Flat Slab Building in the Sudan. Proceedings of the International Conference on Water, Energy, and Food Nexus for Sustainable Development, Pattaya, 19-21 November 2014, Paper No. 5092.

[21] Pednekar, S.C., Chore, S.H. and Patil, B.S. (2015) Pushover Analysis of Reinforced Concrete Structures. International Conference on Quality Up-Gradation in Engineering, Science and Technology, ICQUEST2015, 7-10.

[22] Applied Technology Council (ATC) (1996) Seismic Evaluation and Retrofit of Concrete Buildings. Volumes 1 and 2 , Report No. ATC-40, Redwood City.

[23] Federal Emergency Management Agency, FEMA-356 (2000) Pre Standard and Commentary for Seismic Rehabilitation of Buildings. Washington DC. 